\title{
RATIONALE OF SEARCH TECHNOLOGY ON HYDROGEN AND GEODYNAMIC PHENOMENA (oil and gas regions, mine fields)
}

\author{
I.D. Bagriy¹, P.F. Gozhik², A.A. Repkin ${ }^{3}$, S.A. Kuzmenko", \\ A.A. Loktiev ${ }^{5}$, V.G. Semenuk ${ }^{6}$ \\ ${ }^{1}$ Institute of Geological Sciences of NAS of Ukraine, Kiev, Ukraine, E-mail: bagrid@ukr.net \\ Doctor of geological sciences, senior scientific worker, Deputy director, \\ Head of the department of geoecology and searching. \\ ${ }^{2}$ Institute of Geological Science sof NAS of Ukraine, Kiev, Ukraine, E-mail: info@igs-nas.org \\ Academician of NAS of Ukraine, Director of IGN NAS of Ukraine, Head of the Department of Geology and \\ Geoecology of Antarctic. \\ ${ }^{3}$ The Supervisory Board of "Tokmak Solar Energy», Kiev, Ukraine, the Energy Association "Ukrainian \\ Hydrogen Council», Kiev, Ukraine. \\ Chairman of the Supervisory Board of "Tokmak Solar Energy», President of the Energy Association \\ «Ukrainian Hydrogen Council». \\ ${ }^{4}$ Institute of Geological Sciences of NAS of Ukraine, Kiev, Ukraine, E-mail: kuzma@ua.fm \\ Post-graduate. \\ ${ }^{5}$ Reform support team at Ministry of ecology and natural resources of Ukraine, Kiev, Ukraine, \\ E-mail: shon327@hotmail.com \\ Project manager of subsoil face reform. \\ ${ }^{6}$ LLC «Smart Energy», Kiev, Ukraine, E-mail: v.semenuk@ukrgv.com \\ Chief geologist of LLC «Smart Energy».
}

The results of long-terrn research on mapping of oil and gas bearing sites on traditional and non-traditional sites (mine fields, shelf zones, astroblems) allowed to create a database of system criteria for the search technology of structural thermo-atmo-hydrological and geochemical research, where for the first time in the search practice hydrogen was used as the main constituent element of hydrocarbons. The analysis of the results of the hydrogen concentration distribution data made it possible to isolate anomalous values both in areas and in productive wells (in the absence of background ones) and to conduct detailed area large-scale studies with the purpose of area mapping for prospecting.

Key words: hydro-geosynergic biogenic-mantle theory; hydrocarbons; hydrogen; structural-thermo-atmo-hydrologic-geochemical studies.

\section{ОБГРУНТУВАННЯ ПОШУКОВОЇ ТЕХНОАОГІЇ ВОАНЕВИХ СКУПЧЕНЬ TA ГЕОАИНАМІЧНИХ ЯВИЩ (нафтогазоносні райони, шахтні поля)

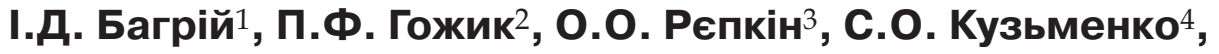 А.А. Локтєв ${ }^{5}$, В.Г. Семенюк ${ }^{6}$}

${ }^{1}$ Iнститут геологічних наук НАН Украӥни, Київ, Украӥна, E-mail: bagrid@ukr.net Доктор геологічних наук, старший науковий співробітник, заступник директора, завідувач відділу геоекології та пошукових досліджень.

${ }^{2}$ Iнститут геологічних наук НАН Украӥни, Київ, Украӥна, E-mail: info@igs-nas.org Академік НАН Украӥни, директор ІГН НАН Украӥни, завідувач відділу геологї та геоекологї̈ Антарктики.

${ }^{3}$ Наглядова рада «Tokmak Solar Energy», Київ, Україна, Енергетична асоиіаиія «Украӥнська воднева рада», Київ, Україна.

Голова наглядової ради «Tokmak Solar Energy», Президент Енергетичної асоиіаиіï «Украӥнська воднева рада».

(C) I.D. Bagriy, P.F. Gozhik, A.A. Repkin, S.A. Kuzmenko, A.A. Loktiev, V.G. Semenuk, 2019 
${ }^{4}$ Інстітут геологічних наук НАН України, Київ, Украӥна, E-mail: kuzma@ua.fm Аспірант.

${ }^{5}$ Команда підтримки реформ при Мінприроди України, Київ, Україна,

E-mail: shon327@hotmail.com

Проектний менеджер реформи надрокористування.

${ }^{6}$ Компанія «Смарт Енерджси», Київ, Україна, E-mail: v.semenuk@ukrgv.com

Головний геолог компанї «Смарт Енерджи».

Багаторічні результати досліджень 3 картування нафтогазоносних ділянок на традиційних і нетрадиційних об'єктах (шахтні поля, шельфові зони, астроблеми) дозволили створити базу даних системних критеріїв пошукової технології структурно-термо-атмо-гідролого-геохімічних досліджень, де складовою частиною комплексу методичних рішень вперше в пошуковій практиці використовувався водень як головний складовий елемент вуглеводнів. Аналіз результатів даних розподілу водневих концентрацій дав можливість виділити аномальні поодинокі значення як по площах, так і по продуктивних свердловинах (при відсутності фонових) і провести детальні площові великомасштабні дослідження з метою площового картування на пошукові роботи.

Ключові слова: гідро-геосинергетична біогенно-мантійна теорія; вуглеводні; водень; структурно-термо-атмогідролого-геохімічні дослідження.

\title{
ОБОСНОВАНИЕ ПОИСКОВОЙ ТЕХНОАОГИИ ВОАОРОАНЫХ СКОПАЕНИЙ И ГЕОАИНАМИЧЕСКИХ ЯВАЕНИЙ (нефтегазоносные районы, шахтные поля)
}

\section{И.Д. Багрий, П.Ф. Гожик², А.А. Репкин³, С.А. Кузьменко4, А.А. Локтев ${ }^{5}$, В.Г. Семенюк ${ }^{6}$}

\author{
${ }^{1}$ Институт геологических наук НАН Украины, Киев, Украина, E-mail: bagrid@ukr.net \\ Доктор геологических наук, старший научный сотрудник, заместитель директора, \\ заведуюший отделом геоэкологии и поисковых исследований. \\ ${ }^{2}$ Институт геологических наук НАН Украины, Киев, Украина, E-mail: info@igs-nas.org \\ Академик НАН Украины, директор ИГН НАН Украины, заведующий отделом геологии \\ и геоэкологии Антарктики. \\ ${ }^{3}$ Наблюдательный совет «Tokmak Solar Energy», Киев, Украина, Энергетическая ассочиаџия \\ «Украинский водородньй совет» Киев, Украина. \\ Председатель наблюдательного совета «Tokmak Solar Energy», Президент Энергетической \\ ассочиачии «Украинский водородный совет». \\ ${ }^{4}$ Институт геологических наук НАН Украины, Киев, Украина, E-mail: kuzma@ua.fm \\ Аспирант. \\ ${ }^{5}$ Команда поддержки реформ при Минприроды Украины, Киев, Украина, \\ E-mail: shon327@hotmail.com \\ Проектный менеджер реформын недропользования \\ ${ }^{6}$ Компания «Смарт Энерджи», Киев, Украина, E-mail: v.semenuk@ukrgv.com \\ Главный геолог компании «Смарт Энерджи».
}

Многолетние результаты исследований по картированию нефтегазоносных участков на традиционных и нетрадиционных объектах (шахтные поля, шельфовые зоны, астроблемы) позволили создать базу данных системных критериев поисковой технологии структурно-термо-атмо-гидролого-геохимических исследований, где составной частью комплекса методических решений впервые в поисковой практике использовался водород как главный слагающий элемент углеводородов. Анализ результатов данных распределения водородных концентраций дал возможность выделить аномальные единичные значения как по площадям, так и по продуктивным скважинам (при отсутствии фоновых) и провести детальные площадные крупномасштабные исследования с целью площадного картирования на поисковые работы.

Ключевые слова: гидро-геосинергетическая биогенно-мантийная теория; углеводороды; водород; структурно-термо-атмо-гидролого-геохимические исследования. 
The use of existing energy sources that causes irreversible destructive processes in the environment, leading to global, almost imminent natural disasters, despite rather costly environmental measures, is one of the major issues of our time, primarily for the development of scientific progress. Clean energy sources become necessary. Currently, there is a need to move thinking to a new level, as the development of technical means and existing concepts does not contribute to progress, but constrains to some extent the mentality and the level of current development. Negative processes occurring as a result of the use of energy facilities such as nuclear energy utilization, burning of billions of tons and cubic meters of combustible minerals and their extraction, lead to a change not only in the environment, but also to the creation of a destructive noosphere, to unpredictable, sometimes catastrophic consequences, practically defying a civilized elimination of them.

As a bright example of a negative impact on the environment, one can mention accidents at nuclear power plants, disasters in oil production at deepsea sites of marine areas, and most importantly, global processes that practically withstand rehabilitation such as ozone holes, climate change, sea currents changes, melting of glaciers, rising of ocean level, etc.

Practically all the listed processes are closely connected with the growing use of outmoded energy sources, which do not meet today's demands for progress development.

Can we find a way out of the current difficult situation? The answer is quite simple, it may be the use of wind, solar energy, and most importantly, the use of a practically inexhaustible renewable source, participating in the endless circulation of matter in nature, the most energyintensive component that is hydrogen.

The introduction of new concepts, scientific research results, including a wide range of scientific and field research, suggests that by 2020 the transition to hydrogen fuel will begin, which in the coming decades will gradually replace traditional fuel and energy resources.

Currently, the most pressing problem thwarting progress in the development of hydrogen energy is not only the high cost of hydrogen produced by electrical decomposition of water and other expensive methods, but also the complete absence of scientific, fundamental and applied ecological and geochemical studies of energy development under conditions of catastrophic environmental degradation such as atmosphere and aquatic environment pollution, immense wastes from nuclear energy, requiring huge costs for their disposal and storage. In this regard, geological and geochemical studies of the possibility of identifying and mapping industrial accumulations of endogenous hydrogen are highly relevant. In other words, the hydrogen issue has, along with the energy aspect, the geological and geochemical ones that are not yet fully realized because of the exceptional focus on traditional hydrocarbon raw materials. At the same time, it is obvious that the hydrogenenergy revolution can fundamentally change the foundations of world energy and the ecological situation of the future. In this regard, the justification and organization of work on assessment of the prospects for identifying industrial accumulations of endogenous hydrogen in the lithosphere should be carried out within the framework of scientific research of the National Academy of Sciences of Ukraine. It is relevant, timely and has a clearly defined innovation component, important for the modernization of the Ukrainian economy and its sustainable socioeconomic development.

Speaking about the issue of hydrogen, we should touch upon a helium issue as well. A large scale release of deep juvenile gases, including helium, was noticed by V.I. Vernadskiy [Вернадский, 2001], who figuratively called this process "the respiration of the Earth". Geologists have long been studying the «gas respiration» of the Earth along deep faults of the lithosphere. Usually such processes were associated with the release of helium-3. There exist two helium isotopes: helium-3 (primary) and helium-4 (radiogenic, arising from the decomposition of uranium and thorium nuclei). Helium-3 is concentrated in the zones of deep faults occurring at the contact of the continental and oceanic crust: in the faults above the Benioff zones, the content of the light isotope is a thousand times higher than in the rocks of the continents. Such a shift in the isotopic ratios indicates that, according to the concept of the origin of hydrocarbons (HC) that we have adopted, gas comes from ultradeep mantle structures as a result of the synthesis of watermethane biogenicoxidized substrates. Hydrogen rises together with helium from the depths of the planet, where it can concentrate, like hydrocarbons and helium, forming industrial accumulations.

We can mention data on the Kola super deep borehole as an example. The super deep (12261 m) 3SGKola borehole opened up oil reservoirs at a depth of $70048004 \mathrm{~m}$, and a natural mud boiling/effervescent with hydrogen flowed from the depth of $12261 \mathrm{~m}$ (face) [Krayushkin, Kutcherov, 2010]. 
Using the discoveries of recent years, the study of various processes in crustal layers and sedimentary cover in zones of deflections - aulacogens carrying components such as carbon, hydrogen, oxidizing oxygen and a wide range of mantle elements, ultrahigh pressures and temperatures that are the synthesis processes of the upper mantle, made it possible to identify the material composition of the Gutenberg layer (lowvelocity zone), thermodynamic, geothermal and geochemical synthesis processes. It was established that at certain thermodynamic and thermoelastic stresses close to critical ones, phase, polymorphic and electronic transformations of elements and, as a consequence, their chemical rearrangements occur in the mantle material [Магницкий, 1965; Белоусов, 1966; Субботин и др., 1964; Чекалюк, 1967]. The remarkable scientist B. Gutenberg [Гутенберг, 1957] made a significant contribution to the knowledge of the mantle processes, as mentioned above. On the basis of data on the internal structure of the Earth, he considered new geochemical and thermodynamic concepts for the transformation of matter in the asthenosphere (mantle) and new development schemes for the main geostructural elements of the earth's crust.

Some features of the development of oil and gas provinces and the conditions of their oil and gas potential, as well as ideas about regularities of formation and location of oil and gas deposits directly within the oil and gas provinces, according to the hydrogeobiogenicmantle paradigm (HGBMP) [Багрий, 2016], indicate that hydrocarbons and their constituents, including hydrogen, are products of replenished closed global circulation of biogenicmantle processes by their nature (according to the theory of V.I. Vernadskiy about the circulation of matter [Вернадский, 2001]) from the constituent elements $\mathrm{O}, \mathrm{H}, \mathrm{C}$ to a wide range of geochemical elements in the Gutenberg layer (lowvelocity zone), including the mantle components $\mathrm{U}, \mathrm{Ra}, \mathrm{He}, \mathrm{Fe}$, and many others as well as S and other chemical elements inherent in geochemical processes. The mantle synthesis forms from the variety of existing elements, apart from the gas component of the $\mathrm{HC}$, two energy phenomena such as the decay products of uranium, radium $-{ }^{4} \mathrm{He}$, and also the most energyecological product hydrogen and, as it will be given below, the isotope of hydrogen ${ }^{3} \mathrm{He}$.

The global nature of genetic accumulations of hydrocarbons is considered in the framework of V.I. Vernadskiy theory on the cycle of matter in nature, where one of the main genetic components of hydrocarbons, both in terms of volume and percentage, is hydrogen, which is the energy basis for lithospheric processes.

For example, oil and gas chemical composition has from 2.5 to 4 hydrogen atoms per carbon atom, while the organic residues of the primary elements of methane contain no more than one hydrogen atom per carbon atom. Therefore, according to the theory of V.I. Vernadskiy on the renewable circulation of matter, it is clear that the issue of hydrocarbons origin is primarily that of the main source of hydrogen.

This interpretation of the relationship between the main components of hydrocarbons served as the basis for creating a new concept of hydrocarbons origin, reflecting a wide range of scientific approaches (geology, geochemistry, hydrology, hydrogeology, geothermics, etc.) which takes into account the renewability of constituent elements (carbon and hydrogen) and results in regeneration of hydrocarbon deposits. This ultimately allows us to approach not only the main issue which is the origin of hydrocarbons and their main energy component - hydrogen, but also the creation of a new highperformance search technology of STAHGS for hydrocarbons and hydrogen [Багрий, 2016]. According to the outstanding Russian geochemist N.B. Vassoevich, donators of chemical elements for mineral synthesis of oil in a certain situation are oxides of hydrogen and carbon, i.e. hydrogen, its oxides and carbon or the above mentioned minerals containing these compounds that are hydrates and carbonates widespread in nature [Вассоевич, 1986].

The variety of chemical compounds in nature, often formed from the same set of chemical elements $\mathrm{H}_{2} \mathrm{O}, \mathrm{CH}_{4}, \mathrm{CO}_{2}$, is caused not only by the influence of the composition of the environment, but, to a large extent, by the thermodynamic conditions in this environment. A wide range of pressures and temperatures in the mantle conditions of synthesis in the Gutenberg layer, makes any substance of any elemental and chemical composition to pass through all possible aggregative and chemical states - from extremely condensed solid ones through liquid to supercritical gas state, and its chemical composition changes from extremely exothermic through endothermic compounds until complete decomposition of compounds into chemical elements. Such transformations cannot be modeled under terrestrial conditions. Therefore, it is natural to expect that among the countless variants of natural thermodynamic and thermogeochemical conditions there may be a possibility for those when only the gas component of 
the hydrocarbon from hydrogen and carbon will inevitably form in a certain mineral medium, since liquid oil, as well as juvenile water, cannot be produced in ultrahigh mantle temperatures, and, as it was mentioned earlier, are the product of a retrograde process in crystalline rocks and sedimentary cover.

At pressures above $50 \mathrm{kbar}$ and temperatures above $1500 \mathrm{~K}$ existing there, hydrocarbon systems similar in composition to the hydrocarbon portion of oil (gas hydrocarbons) appear to be thermodynamically balanced, stable geochemical systems. A significant role in forming energy products - HC and hydrogen - is played by pore waters coming from artesian basins, bringing dissolved $\mathrm{H}, \mathrm{CH}_{4}$, and $\mathrm{H}_{2} \mathrm{O}$ [Бабинец, Белявский, 1973].

Convincing evidence of the presence of vaporous water and carbon dioxide in the mantle at these depths is given in the monograph by E.K. Markhinin [Мархинин, 1967], who showed that the upper mantle is the main supplier of materials for the construction of all upper shells of the Earth, i.e. the crust, lithosphere, hydrosphere and atmosphere. According to this viewpoint, an average of about $180 \mathrm{~kg}$ of water flowing in the form of pore gravitational waters [Бабинец, 1973] and about $15 \mathrm{~kg}$ of carbon dioxide are contained in $1 \mathrm{~m}^{3}$ of mantle substance, which coincides with the estimates of many other researchers of the mantle composition.

Due to the fact that water cannot be a mantle product, its presence can be explained only from the point of view of pore waters migrating through infiltration zones with dissolved rudimentary methane to the mantle - the Gutenberg layer [Бабинец, 1961], within which there is a combination of all necessary factors contributing to the inorganic synthesis of hydrocarbon elements coming from the sedimentary layer in the form of dissolved methane, according to supporters of biogenic origin of hydrocarbons,. The presence of juvenile water in the mantle mass described in the works of many authors is rather problematic. Hydrogen, oxygen and carbon are the three main components that come with pore waters [Бабинец, 1973] in the form of biota oxidation products in the process of circulation of a substance [Вернадский, 2001].

Thus, the synthesis of the incoming $\mathrm{H}_{2} \mathrm{O}, \mathrm{CH}_{4}$ rudimentary elements creates conditions for the derivation of both complex hydrocarbon elements and the products of their synthesis $\mathrm{H}, \mathrm{C}$, since, according to HGBMP, hydrogen and carbon reserves in the mantle in the contact zones are constantly replenished from upper shell of the Earth under conditions of the cycle of matter in nature due to geodynamic processes. Under the conditions of synthesis, gasenergy components are created in the mantle mass such as the hydrocarbon spectrum, hydrogen, and their accumulations.

The ultimate saturation with hydrogen, the main energy component, was recorded in various theories of the formation of natural hydrocarbons. In recent years, numerous options have arisen for producing hydrogen from the deep zones of the earth's crust [Стадников, 1937; Соколов, 1965] or from organic compounds by disproportionation and methanization, extraction of hydrogen from water [Гринберг, 1971; Порфирьев, Гринберг, 1966; Порфір'єв, 1968]. These methods are not yet available either for production or in laboratory conditions due to the lack of technology.

It is also known that in the history of oil genesis study, there was a problem of oil original forms from organic matter, which constitutes the cycle of circulation consolidated with hydrogen.

It seems that the group composition of deepseated hydrocarbon fluids in contact equilibrium with condensed matter of the mantle depends on the composition of these components, which contain an equilibrium system of chemical compounds of three elements, namely $\mathrm{C}, \mathrm{H}, \mathrm{O}$, as well as $\mathrm{U}$ and $\mathrm{Ra}$ (which explains the radioactivity of oils), sulfur compounds, and, in addition, groups of unsaturated hydrocarbons found in oils and some gases: $\mathrm{CO}_{2}$, $\mathrm{CO}, \mathrm{NH}_{3}, \mathrm{H}_{2} \mathrm{~S}, \mathrm{He}$, etc. Thus, it can be assumed that not only oillike systems are formed in the process of mantle synthesis, but also hydrogen, as the initial rudimentary component of the hydrocarbon, as a result of thermodynamic and geochemical processes according to the origin of the hydrocarbon (hydrogen) proposed by HGBMP.

The mapping of hydrocarbons and hydrogen can only be successful with a comprehensive consideration of recent advances in petroleum geology and geochemistry. It should be noted that in recent years, processes of genesis, migration, and the formation of industrial oil and gas fields have often been mistakenly associated only with large deep faults in various zones of the earth's crust and upper mantle [Доленко, 1962; Порфір'єв, 1968; Субботин и др., 1964; Павлюк та ін., 2012]. In our opinion, they serve as zones of multidirectional migration of gases and fluids, rather than the genetic conditions for their origin. 
The above mentioned ideas about the interaction of volatile and condensed phases under conditions of a gravitational field result logically from the wellknown physical laws of a degassed body and retrograde transformations. The generally accepted initial principles underlying the concepts simply explain a wide range of phenomena observed in nature, in particular, the seismic properties of the Gutenberg layer, the cyclical nature of geotectonic processes, the geological similarity of deposits of various minerals, the processes of fluid accumulation and migration associated with geodynamic phenomena and geothermal processes both of receipts and of the removal of hydrocarbon components from the mantle to the upper shell of the Earth, etc. Deep faults originate mainly in deepseated concentration of elastic energy, and from there they spread upwards through hydraulic fractures, under which conditions dikes and stocks can be extruded. In this case, both horizontal and vertical shifts are possible. The pressure in the zone of fault at great depths always exceeds the geostatic pressure. Such processes and their derivatives serve as criteria indicators of hydrocarbon derivatives and their components, which are hydrogen and helium.

One of the most important issues in achieving the goal is the following question: where it is possible to find an accessible and abundant source of hydrogen to solve environmental and energy problems. As of today there are almost no justifications for the search for industrial accumulations of hydrogen in the world practice and, as a result, the technology of its extraction.

There occur zones of hydrogen anomalies found at oil and gas fields although they are rare. In Sweden, while drilling the Gravberg1 well, $6770 \mathrm{~m}$ deep, a significant increase in the hydrogen content was noticed below a depth of $4000 \mathrm{~m}$.

A number of phenomenacriteria can be explained basing on the general information of the proposed new HGBMP of $\mathrm{HC}$ origin, that are directly related to the origin and the search for $\mathrm{HC}, \mathrm{H}, \mathrm{He}$ deposits. At the same time, we would like to point out the following: in accordance with the geological age of oil and gas provinces, we can speak of the geochemical and thermodynamic conditions of formation and migration of hydrocarbons and their components $\mathrm{H}$ and $\mathrm{C}$ within the piedmont depressions, intermountain areas, platform slopes, intraplatform depressions, river systems obeying a single concept that is the circulation of rudimentary elements of watermethane compounds bearing $\mathrm{CH}_{4}, \mathrm{CO}_{2}, \mathrm{H}_{2} \mathrm{O}$, and the basic mantle products of the synthesis of $\mathrm{C}, \mathrm{H}, \mathrm{O}_{2}$.
Where should we look for the place of generation of such a demanded energy source? Studies in the field of hydrogen extraction carried out by Russian scientists point to a connection between the prospects for hydrogen production, volcanic activity and fire belts, which, in our opinion, is incorrect from both practical and scientific points of view.

However, the great experience gained by the author in mapping gas halos gives hope for the discovery of natural deposits not only of hydrocarbons, but also of helium and hydrogen.

The technology of structuralthermoatmohydrologicgeochemical studies (STAHGS) [Багрій, 2013] based on the HGBMP origin of hydrocarbons was developed and tested, which allows identifying local areas of hydrogen degassing anomalies, opens up fundamentally new possibilities for mapping promising areas for detailed search studies not only for the industrial production of hydrocarbons and, possibly, hydrogen, but also for mapping outburstprone areas when mining coal.

Below we will consider regularities of origin and location of hydrogen and its derivatives on the basis of the proposed HGBMP origin of hydrocarbons and their main component that is hydrogen, we will present the results of scientific mapping carried out in the framework of scientific and practical exploratory and geoecological studies of more than 165 hydrocarbon units on land and in marine areas [Багрий, 2016]. Our areal atmogasgeochemical surveys carried out within the framework of the new STAHGS search technology at promising licensed petroleumbearing structures allowed mapping the presence of anomalous sites of hydrogen and helium concentrations exceeding background values hundreds or more times. Such sites, mapped after their topcut concentrations, are of undoubted search interest in extensive research studies as phenomena of the energy source, as well as in terms of geoecological forecasts for making decisions about the safety of mining operations.

Only in the established heterogeneity of hydrobiological processes in the lithosphere and mantle matter, the differences in its temperature regimes in different regions, should we expect planetary, regular, ubiquitous oilbearing capacity, in zones of continental troughs. The regional location of oil and gas provinces serves as a search prerogative for locating renewable biogenic sources of hydrocarbons in the form of rudimentary products of organic compounds and biochemical processes associated with river systems in sedimentary cover zones, deltas, estuaries, 
canyons, represented in the latter by stratigraphic units of marine areas and almost universally recorded in the process of detailed areal surveys of the full range of $\mathrm{HC}$ components and their derivatives $\mathrm{H}, \mathrm{CO}_{2}$, He. This made it possible in the end to map the anomalous zones of hydrogen degassing sites for further fulfillment of detailed forecastingprospecting works for industrial hydrogen accumulations.

Gassaturated areas of hydrocarbon anomalies located, probably under conditions of the predominance of mantle processes that generate gas composition, containing almost the full spectrum of carbon, hydrogen, helium appear to be the most mapped areas of hydrogen. The choice of regions and structures that are promising for prospecting, exploration and production of natural hydrogen should be based on the basic laws of its spatial areal distribution. However, the literature data characterizing the hydrogen degassing of the planet as a whole, as well as its individual regions, are extremely scarce, segmental, fragmentary and obtained by various authors at different times, they are often contradictory and practically not scientifically substantiated. It is practically impossible to form a holistic view of the spatial and temporal regularities of hydrogen degassing on their basis.

Therefore, having significant experience in detailed mapping of gas elements $\left(\mathrm{Rn}, \mathrm{Tn}, \mathrm{CO}_{2}, \mathrm{He}\right.$, $\mathrm{HC}$ spectrum, and $\mathrm{H}$ ) in more than 165 areas - bearers of hydrocarbonhydrogenhelium components, with a total area of more than $15000 \mathrm{~km}^{2}$ on land and in sea areas, we conducted the first attempt to summarize the results of our own scientific research on the selection of promising areas for more targeted research in search for not only $\mathrm{HC}$, but also $\mathrm{H}, \mathrm{He}$ (See Figure).

Any hypothesis, supported by sufficiently reliable experimental studies, has the right to be given the title of scientific only if the foundations of its experimental examination can be formulated (the principle of verification). To test the described above hypothesis and the reliability of the mapping results obtained by us at oil and gas bearing structures, where significant hydrogen contents were recorded, control test measurements were carried out at representative units such as: traditional oil and gas bearing structures (Nedelnaya, Vasishchevskaya); unconventional ones - astroblems (Boltyshskaya, Obolonskaya), mining methane production sites (Tomashevskaya area, a group of mine fields of Lisichansk domes), promising and productive marine structures (Subbotina, Britanskiye). The issue of possible gasdynamic phenomena in the workings of the mines Zasyadko North and South, «Stepnaya», «Krasnolimanskaya».

It is also necessary to take into account that deep degassing is a pulsed process, which means that, longterm series of observations are needed to quantify it. However, the scale of hydrogen degassing can be judged by the estimated degassing of helium, which in comparable quantities is a companion of hydrogen in deep currents, but, unlike the latter, it is much better studied.

Below we give a theoretical substantiation for the zones where hydrocarbon and hydrogen accumulations are located and mapped according to a new oil and gas zoning in Ukraine based on the results of research and production studies.

The issue of the search for hydrogen was considered by us in the light of the general regularities according to the HGBMP origin of hydrocarbons and on this basis a direct search technology for $\mathrm{HC}$ (STAHGS) was created where hydrogen is one of the required elements of the forecastproductive areas. The hydrogen atom, the simplest, smallest and lightest of all types of existing atoms, is of considerable interest in the study of filtrationdiffusion processes, is the most effective direct search criterion as a constituent element of hydrocarbons and is well mapped even in conditions of impermeable oil and gas bearing covering structures.

A comprehensive analysis of geological and structural, hydrological and hydrogeological materials carried out for almost 30 years as part of scientific fundamental and applied research at prospect sites in order to substantiate the mapping of promising places for sinking parametric and industrial wells for drinking, thermal waters, hydrocarbons (oil, gas), degassing wells in the areas of development of gasdynamic phenomena in mine workings, allowed defining the spatialquantitative characteristics of hydrocarbon deposits and their emanationgas indicators: $\mathrm{Rn}, \mathrm{Tn}, \mathrm{He}, \mathrm{CO}_{2}, \mathrm{H}$.

Based on the new concept (paradigm of HC origin), a new scheme of oil and gas hydrogeological zoning of Ukraine at traditional and nontraditional oil and gas search objects, including astroblems, marine areas and coalrock massifs, has been created. It is based on oil and gas bearing geological, structural, hydrogeobiological criteria for the formation of primary hydrocarbon compounds and components, taking into account the geodynamic features of structural and tectonic principles developed by I.I. Chebanenko, 


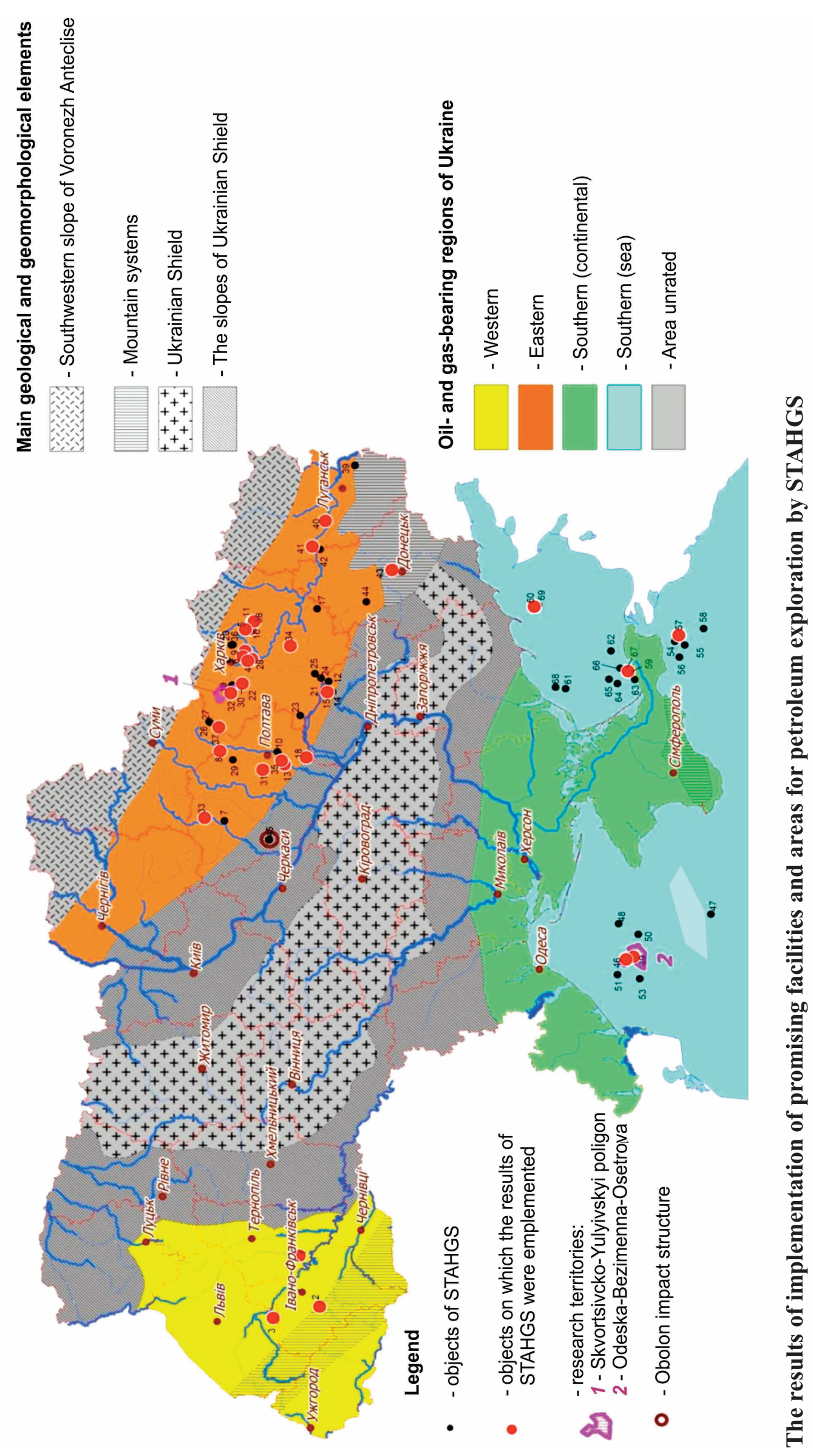


V.K. Gavrish, hydrogeological works of A.E. Babinets and the hydrological works of I.D. Bagriy.

As practice has shown, this approach even at the preliminary stage of research allows convincing determining not only the degree of concentration of promising areas of oil and gas regions, discarding practically unproductive areas, but also revealing anomalous areas of concentrations of one of the main energy components - hydrogen, not only as a renewable energy source of the circulation substances in nature, but also as a detonator of geodynamic phenomena in mine workings leading to catastrophes and human casualties.

When determining the oil and gas potential at each studied traditional and nontraditional structure (area or ground) using the STAHGS method, a full range of technological approaches was worked out, including structuralgeological, aerospace, geothermal, and geochemical studies. In addition, the research complex included studies of hydrological and hydrogeological features of hydrocarbon components formation in the areas of the structures under study for the spectrum of hydrocarbon elements, which are based on hydrogen.

At the initial stages of research, the emanation components $\mathrm{Ra}, \mathrm{Tn}$ and gas $\mathrm{He}, \mathrm{H}$ were used as indicators of fracture zones of increased permeability to solve geoecological and prospecting tasks for underground and thermal waters [Багрій, 2003].

Analysis of the results of gasemanation areal surveys, including $\mathrm{H}$ and $\mathrm{He}$, allowed a new approach to one of the components of hydrocarbon gases that is hydrogen, the main energy component of the Universe.

The conceptual interpretation of the results of the STAHGS prospecting concept allowed, at the preliminary regional search stage, to distinguish 25 offshore and 98 on land productive oil and gas bearing areas (success rate is approximately $90 \%$ ), and also to record significant concentrations of hydrogen in single productive gas wells within the target areas.

The recording of abnormally extreme manifestations of hydrogen by areal surveys after geological, structural, geothermal, and other features (STAHGS) at the completed units did not allow us to establish the pattern of distribution of extreme values of hydrogen in the studied areas. Therefore, it is necessary to conduct more detailed areal surveys in zones of areal hydrogen anomalies and hydrogensaturated wells, with mapping details of hundreds or even tens of meters, which would allow delineating areal hydrogen anomalies in order to substantiate scientificparametric studies in both planimetric and vertical sections.

The results of many years of research on mapping oil and gas areas on traditional and nontraditional units (mine fields, offshore zones, astroblems) allowed us to create a database of system criteria for the STAHGS search technology. Hydrocarbon as the main component of HC was used for the first time in search practice as a constituent of the range of method solutions.

Below, in the context of hydrogenenergy topics, geoecological processes will be considered in areas of possible accumulationgeneration of hydrogen and methane gases, which now traditionally serve as explosion risk markers and cause enormous destruction in confined mine spaces, resulting in material losses, leading to ceasing production cycles for a long period, and most importantly, to significant human casualties.

Many authors, investigating geodynamic processes, the component composition of gases, consider methane to be highly explosive and associate with it emissions, leading to catastrophes of different scales. The overwhelming amount of gas control in mine workings is associated with methane fixation. In case of increase of methane concentrations to the critical level, the sensors should notify the incident and disconnect the mining equipment from energy sources.

The analysis of the explosions in the mines of Ukraine, Russia suggests that the occurrence of contingency situations, explosions occurred in the complete absence of methane danger alarms. Explosions were recorded at the Raspadskaya mine (Russia) at a depth of $120 \mathrm{~m}$, and at the mine named after C.M. Kirov (Donbass) at a depth of $110 \mathrm{~m}$. These and many other factors indicate the complete absence of any connection between catastrophic phenomena and depth.

Thus, having analyzed significant amount of materials on casual producing capacities, we can assume the fact that the sudden opening up of methanebearing reservoirs and the influx of significant amounts of methane into the mine workings were not the possible causes of outburstprone processes, but anomalous areas of elevated hydrogen content entering the coalmassif from the mantle horizons. It was established when studying and analysing a huge amount of factual material based on areal gasgeochemical surveys. No relationship between catastrophes and geological processes was recorded, and it was not possible to determine patterns of areal distributions of hydrogen. 
Such significant concentrations of hydrogen (up to $1 \%$ in the area of mine workings) afforded ample grounds for conducting detailed areal and profile studies along the surface of mining faces, traced on surveying plans.

Significant concentrations of hydrogen, mapped in the process of detailed research, can be viewed in the context of water influx in mine workings as an integral part of fire damp, especially in the presence of even minor sources of fire - sparking, metal impacts, compression loads, not excluding the tectonic factor.

Ultrahigh temperatures and enormous dynamic loads leading to rupture of solid metal structures of mining equipment such as rails, buckets, etc. accompany the explosions of hydrogen mixtures.

The mapping of explosive hazard areas and the admitting of advanced degassing drilling can be carried out conducting very detailed geochemical areal and profile surveys according to the STAHGS technology [Багрій та ін., 2011].

Performed research in prospecting and mapping of promising areas for commercial contents of subsurface hydrocarbon deposits (the deposit was discovered for the first time in the "Toma-

\section{Список літератури}

Бабинец A.E. Подземные воды юго-запада Русской платформы. Киев: Изд-во АН УССР, 1961. $378 \mathrm{c}$.

Бабинец А.Е., Белявский Г.А. Естественные ресурсы подземных вод зоны интенсивного водообмена Украины. Киев: Наук. думка, 1973. 111 с.

Багрій І.Д. Прогнозування розломних зон підвищеної проникності гірських порід для вирішення геоекологічних та пошукових задач. Київ: ТОВ «Вид. дім Дмитра Бураго», 2003. 149 с.

Багрій І.Д., Гожик П.Ф., Почтаренко В.І., Аксьом С.Д., Дубосарський В.Р., Мамишев I.Є., Kiзлат A.M., Палій В.M. Прогнозування геодинамічних зон та перспективних площ для видобутку шахтного метану вугільних родовищ Донбасу. Київ: Фоліант, 2011. 236 с.

Багрій І.Д. Розробка геолого-структурнотермо-атмогеохімічної технології прогнозування пошуків корисних копалин та оцінки геоекологічного стану довкілля. Київ: Логос, 2013. 510 с.

Багрий И.Д. Гидро-геосинергетическая биогенно-мантийная гипотеза образования углеводородов и ее роль при обосновании прямопоисковой технологии. Геол. журн. 2016. № 2 (355). С. 107-133.

Белоусов В.В. Земная кора и верхняя мантия материков. Москва: Наука, 1966. 120 с. shevskaya" area mine field in the development zone of the Lisichansk domes, which produced industrial gas volumes (implementation report) revealed for the first time anomalous points that are areas with significant hydrogen content.

As part of the implementation of scientific topics over the past years, geochemical detailed studies of mine fields ("Tomashevskaya" area, Lisichansk domes, including the Kapustin mine, "Privelnyanskaya", "Novodruzhevskaya", "Tomashevskaya Severnaya", "Tomashevskaya Yuzhnaya" mines, as well as existing Zasyadko mines, "Krasnolimanskaya" mine in the Donetsk Basin, mines "Stepnaya" and "Lesnaya" in the Lviv-Volyn Basin).

Conducted research on the mapping of promising areas to search for hydrocarbons in the zones of development of coalbearing massifs according to the STAHGS technology, anomalous pointwise values of hydrogen were mapped, by 23 orders of magnitude higher than the values of methane and its homologues in almost all of the studied areas of the mines and operating mines of the Donbass and LvivVolyn basin.

Analysis of the data results of the distribution of hydrogen concentrations allowed us to identify anomalous unit values for areas, profiles, productive wells.

Вассоевич Н.Б. Избранные труды. Геохимия органического вещества и происхождение нефти. Москва: Наука, 1986. С. 324-339.

Вернадский В.И. Химическое строение биосферы Земли и ее окружения. Москва: Наука, 2001. $376 \mathrm{c}$.

Гринберг И.В. Некоторые химические аспекты проблемы генезиса теорий. Проблема происхождения нефти и газа и формирование их промышленных залежей. Киев: Наук. думка, 1971. С. 52-67.

Гутенберг Б. Скорости распространения сейсмических волн в земной коре. Земная кора: Полдерварт А. (ред.). Москва: Изд-во иностр. лит., 1957. С. 121-138.

Доленко Г.Н. Геология нефти и газа Карпат. Киев: Изд-во АН УССР, 1962. 367 с.

Магницкий В.A. Внутреннее строение и физика Земли. Москва: Недра, 1965. 380 с.

Мархинин E.K. Роль вулканизма в формировании земной коры. Москва: Наука, 1967. 256 с.

Павлюк М., Наумко І., Макітра Р., Брик Д. Про ймовірну модель утворення природних вуглеводнів у літосфері Землі. Геологія і геохімія корисних копалин. 2012. № 1-2. С. 158-159.

Порфирьев В.Б., Гринберг И.В. Современное состояние теории органического происхождения 
нефти. Проблемы происхождения нефти. Киев: Наук. думка, 1966. С. 5-51.

Порфір'єв В.Б. До питания про умови формування промислових скупчень. Геол. журн. 1968. Т. 28, вип. 4 (121). С. 3-31.

Соколов В.A. Процессы образования и миграции нефти и газа. Москва: Недра, 1965. 276 с.

Стадников Г.Л. Происхождение углей и нефти. Москва; Ленинград: Изд-во АН СССР, 1937. $611 \mathrm{c}$.

\section{References}

Babinets A.E., 1961. Groundwater of the southwestern part of Russian platform. Kiev: Izdatelstvo AN USSR, 378 p. (in Russian).

Babinets A.E., Bielawskiy G.A., 1973. Natural ground-water resources within intense water exchange zone. Kiev: Naukova Dumka, 111 p. (in Russian).

Bagriy I.D., 2003. Prediction of fracture zones of high permeability of rocks to solve search and geoecological problems. Kyiv: LLC «Dmytro Burago Publishing House», 149 p. (in Ukrainian).

Bagriy I.D., Gozhik P.F., Pochtarenko V.I., Aksyom S.D., Dubosarsky V.R., Mamyshev I.E., Kizlat A.M., Paliy V.M., 2011. Forecasting of geodynamic zones and promising areas for coal mine methane mining in Donbas coal fields. Kyiv: Foliant, 236 p. (in Ukrainian).

Bagriy I.D., 2013. Development of geologicalstructural-thermal-atmogeochemical technology of forecasting of search of minerals and assessment of geoecological environmental state. Kyiv: Logos, 511 p. (in Ukrainian).

Bagriy I.D., 2016. Hydro-geosynergetic biogenicmantle hypothesis of hydrocarbons origin and its role in direct search technology substantiation. Geologichnyy zhurnal, № 2 (355), p. 107-133 (in Russian).

Belousov V.V., 1966. The Earth's crust and the upper mantle of the continents. Moscow: Nauka, 120 p. (in Russian).

Vassoevich N.B., 1986. Selected works. Geochemistry of organic matter and the origin of the oil. Moscow: Nauka, p. 324-339 (in Russian).

Vernadskiy V.I., 2001. The chemical structure of the Earth's biosphere and its environment. Moscow: Nauka, 376 p. (in Russian).

Grinberg I.V., 1971. Some chemical aspects of the problem of the genesis of theories. In: The problem of the origin of oil and gas and the formation of their industrial deposits. Kiev: Naukova Dumka, p. 52-67 (in Russian).

Gutenberg B., 1957. Velocities of propagation of seismic waves in the earth's crust. In: Earth's crust.
Субботин О.И., Наумчик Г.Л., Рахимова Н.Т. Процессы в верхней мантии Земли и связь с ними строения земной коры. Киев: Наук. думка, 1964. $136 \mathrm{c}$.

Чекалюк Э.Б. Нефть верхней мантии Земли. Киев: Наук. думка, 1967. 258 с.

Krayushkin V.A., Kutcherov V.G. Deep-seated abiogenic origin of petroleum: From geological assessment to physical theory. Rev. Geophys. 2010. Vol. 48. No 1. P. 1-30.

(Ed. A. Polderwart). Moscow: Izdatelstvo Inostrannoy Literatury, p. 121-138 (in Russian).

Dolenko G.N., 1962. Geology of oil and gas in the Carpathians. Kiev: Izdatelstvo AN USSR, 367 p. (in Russian).

Magnitskiy V.A., 1965. The Earth inner structure and physics. Moscow: Nedra, 390 p. (in Russian).

Markhinin E.K., 1967. Role of Volcanism in the Formation of the Earth Crust. Moscow: Nauka, 267 p. (in Russian).

Pavlyuk M., Naumko I., Makitra R., Brick D., 2012. On the probable model of the formation of natural hydrocarbons in the lithosphere of the Earth. Geologya i geokhimiya goruchykh kopalyn, № 1-2, p. 158-159 (in Ukrainian).

Porfiryev V.B., Grinberg I.V., 1966. The current state of the theory of the organic origin of petroleum. In: Problems of the origin of oil. Kiev: Naukova Dumka, p. 5-51 (in Russian).

Porfiryev V.B., 1968. On the conditions of formation of industrial accumulations. Geologichnyy zhurnal, vol. 28, iss. 4 (121), p. 3-31 (in Ukrainian).

Sokolov V.A., 1965. The processes of formation and migration of oil and gas. Moscow: Nedra, $276 \mathrm{p}$. (in Russian).

Stadnikov G.L., 1937. The origin of coals and oil. Moscow; Leningrad: Izdatelstvo AN USSR, 611 p. (in Russian).

Subbotin O.I., Naumchik G.L., Rakhimova N.T., 1964. Processes in the upper mantle of the Earth and it relationship with the structure of the earth's crust. Kiev: Naukova Dumka, 136 p. (in Russian).

Chekalyuk E.B., 1967. Oil of the upper mantle of the Earth. Kiev: Naukova Dumka, 258 p. (in Russian).

Krayushkin V.A., Kutcherov V.G., 2010. Deepseated abiogenic origin of petroleum: From geological assessment to physical theory. Rev. Geophys., vol. 48, No 1, p. 1-30 (in English).

Received 08.05.2019 